\title{
Ideologies Reflected in the Selected Speeches of Ho Chi Minh
}

\author{
Nguyen Thi Hong Minh, Ph.D*, Maria Luisa A. Valdez, Ph.D \\ Thai Nguyen University of Education, Socialist Republic of Vietnam \\ Batangas State University ARASOF Nasugbu, Republic of the Philippines
}

*Corresponding Author: Nguyen Thi Hong Minh, Ph.D., Thai Nguyen University of Education , Socialist Republic of Vietnam.

\begin{abstract}
The present stage of human social development and organization is grounded on communication. Although communication is ruled by broadcast and print media as well as online and mobile technologies, the speeches remain a fundamental medium of political communication worldwide. Oftentimes, the speeches and the speakers' style can delineate an entire situation in such a memorable and operative way that it contributes to historical transformation.Thus, this qualitative study analyzed the political ideologies reflected in the selected speeches of Ho Chi Minh and their implication to the thinking of Vietnamese youth. Findings of the analysis revealed that Ho Chi Minh's selected speeches vividly exhibited the aspects of his political ideologies as expressed in his ideological strategy on continuous proletarian revolution specifically on national liberation manifested through independence and unity; on national independence and unity expressed through democracy, freedom, welfare and happiness; and on socialism as one of his ideologies' major creative points. Moreover, the manifestations of the themes of patriotism, humanism, inner peace and moral philosophy are also evident in the literary works. With regard to the implications of his ideologies to the thinking of the Vietnamese youth, Ho Chi Minh's ideologies serve as the lighting torch leading the youth towards positive thinking, good virtues and practical actions contributory to the building and defense of their country.
\end{abstract}

Keywords: Ho Chi Minh, Ideology, Marxism-Leninism, Speeches, Socialism, Vietnam

\section{INTRODUCTION}

Literature has a germane purpose within the perspective of society and history. It can provide people the language with which to intellectualize and discuss about their experiences. This access to the language of experience provides them access to their own experiences in a manner that they did not earlier have and traces that experience within a cultural, social or political frame. Lye (2008) [1] cited that man's ability to conceptualize, to analyze and to some extent to feel is sustained by their ability to utilize language appropriately and extensively. To utilize the methods of communication in defined and effective ways is the role of literature.He added that to engage oneself in literature is to engage oneself in a continuing process of refining one's capacities to use language and one's sensibilities to good language use. Moreover, literature, teaches people to be more mindful of the whole range of ideas, images, symbols, and feelings, which underpins their private, social as well as political lives.

The present stage of human social development and organization is grounded on communication. The humanities including, arts, cultures, histories, and languages hinge on and flourish through communication. Like any art form, Lye [1] emphasized that literature engages the readers in a complex set of intellectual, moral, social and symbolic considerations. It utilizes codes, images, symbols, stories and language as ordinary means of communication but employs them with more subtlety and complexity than is typical in daily communication. On the other hand, language as a continuous and productive linguistic device is used by speakers to express ideas, feelings, views and convictions. It is a subtle tool whose inappropriate usage can distort or mar the speaker's opinions, views, and feelings. Literature and language could be the writers' channel for conveying their ideologies.

World leaders, politicians and even activists conveytheir ideologiesthrough literature and language. An ideology is a collection of normative beliefs and values that an individual or group holds for other than purely cognitive reasons[2]. A political ideology is a coherent set of views on the role of the government and on politics. The hallmark of a political ideology is consistency over a wide range of 
issues [3]. Political ideologies shape public policy debates as well as the social policy strategies developed to address social problems [4].

Likewise, world leaders deliver a good deal of speeches like official statements, press conferences, parliamentary debates, platform speeches, televised addresses, songs, cheers and jeers. Oftentimes, the speeches and thestyle they use can delineate an entire situation in such a memorable and operative way that it contributes to historical transformation. Instead of deliberating about socialism and communism, democracy and fascism, with reference to the relevant problems raised by those issues, they want to bring in a discussion of such issues into their discourses or speeches. They seek to think through, to deliberate and to teach people in a casual or evenin an indirectmanner the sternest challenges faced by humanity.

Today, although communication is ruled by broadcast and print media as well as online and mobile technologies, the speeches remain a fundamental medium of political communication worldwide. The rhetoric of television news reporting, the "opposite the editorial page" columns and blogs is essential and can be influential. But the speeches retain its effectiveness and closeness between people that gives them the power to reshape the feelings and opinions of those who are present to hear them. If people are to understand how politics works, and if they are to support and strengthen any political group, then one of the things they need to do is appreciate the place within it of such political rhetoric.

The scholarly study of rhetoric and literature can convey much about how politics works and how people think politically. People can learn about the diverse reasons they provide in political argument and see if these change over time, or if some kinds of arguments are more often found in association with one ideology or political position rather than another [5].

To share one's ideology is to find valuable reasons for people to feel and think something, and of the finest and most compelling way to communicate these to them. That is why rhetoric and literature are the fundamental components of political life in a free society. One that when put into use well may be commended. Thus, world leaders and politicians try toinfluence their listeners to believe in their political ideologies as well as share their concepts about patriotism, humanism, inner peace, and moral principle.

Ho Chi-Minh was a nationalist revolutionary and president of North Vietnam from 1954 to 1969. He organized the Intercolonial Union, was elected to the Committee of the Peasants' International Congress and took charge of China's Indochinese Communist party. He declared Vietnam's independence and became the first president of the republic in 1954 [6]. It is significant to note that the success of Vietnam's August Revolution of 1945 can be attributed in part to Ho Chi Minh's reconstitutive rhetoric. In 1998, HồChí Minh ranks among the most influential leaders in the world. Time magazine listed him in the list of 100 Most Important People of the Twentieth Century [7]and [8].After World War II, his ideologies and revolution inspired many people and leaders in Africa, Asia, and Latin America during the decolonization movement on a global scale. He was one of the international figures highly regarded and praised in the Communist world [9].

Ho Chi Minh's form of rhetorical discourse gave the Vietnamese people a new sense of identification. In turn, this rekindled identity stirred up a renewed demand for independence and nationalism. $\mathrm{He}$ utilized his persuasive ability and the cultural heritage of the Vietnamese people as a channel of shaping his persona. In appreciating his unique form of discourse, readers may catch sight of how he was able to unify his country in order to sustain a long-drawn-out struggle with the aim of securing national independence [10].

The relevance of this literary analysis is highlighted with reference to its importance to the working professionals, college instructors of literature, students of literature, the researchers, and future researchers. This study may be beneficial for the working professionalslike the intelligent readers, scholars of rhetoric, politically engaged, and anyone interested in understanding how the prudent use of language in highly charged contexts can make a notableimpact to the study of contemporary political discourse and public rhetoric. This research may be beneficial to the College instructor's methodology in teaching literature specifically the use of suitable approaches in the analysis of political ideologies. This paper may also motivate the students to regard literature as a work of art notable from other texts through content and eventually intensify their appreciation of speeches as well asencourge them to engage in literary analysis as a scholarlyendeavor. The researchers may be 
benefitted by this study in the sense that this analysis may serve as their modest contribution to the existing limited body of researches about the life of Ho Chi Minh and to the growing body of his literature. Finally, the future researchers may use this paper as a frame of reference when they conduct researches about literature as a form of communication.

\section{OBJECTIVES OF THE STUDY}

This study analyzed the political ideologies reflected in the selected speeches of Ho Chi Minh and their implication to the thinking of Vietnamese youth. Likewise, this paper identified the themes of patriotism, humanism, inner peace and moral principle as manifested in the literary works.

\section{Materials ANd Methods}

\subsection{Research Design}

This study employed the qualitative method of research. Qualitative research is bounded by the philosophical premise that one must take into consideration the multiple realities experienced by the participants themselves to understand a complex phenomenon, according to Suter (2012) [11]. These multiple realities experienced by the participants can be manifested in various ways, including the literary genre referred to as discourses or speeches.

Human experiences take their meaning from cultural, social and political impacts, and are therefore incapable of being disconnected from the said influences, according to Ary et al. (2006) [12]. Hence, in analyzing the identified literary works, the political ideologies in the context of being a world leader were considered. These provided substantial and significant interpretations of the authors' motivations as regards Ho Chi Minh's ideologies.

Patton (2002) [13] pointed out that the goal of qualitative data analysis is to uncover emerging themes, patterns, concepts, insights, and understanding. Thus, this study also involved content analysis, which is a systematic method of analyzing message content and message handling.The analysis in this research centered on the extraction of meaning and pattern seeking from Ho Chi Minh's selected literary narrative or image data. Substantial effort was concentrated on the task of making notes through concepts, coding and categories; linking and combining abstract concepts; extracting the essence; organizing meaning; analyzing and interpreting; and drawing conclusions.

To attain congruency between the theories used in explaining the concept of ideology, making notes through concepts and categories were conducted. In this study, the categories which served as coding units include the following: the ideologies reflected; the themes manifested in the selected speeches like patriotism, humanism, inner peace, and moral principle; and the implications of his ideologies to the thinking of the Vietnamese youth.

Moreover, this analysis used the sociological and philosophical approachesas the bases for analysis. Likewise, other approaches in literary criticism that may be employed in the analysis like the Biographical Criticism, Gender Criticism and Psychological Criticism were excluded in the analysis.

\subsection{Materials for Criticism}

The representative literary work analyzed wasHo Chi Minh's Selected Articles and Speeches (19201969) [14]. It is a collection of Ho Chi Minh's writings and speeches during the period from 19201969. The bulk of the selection focuses on writings and speeches at each stage of the Vietnam struggle. The said literary work was chosen because of its correlation with the aforementioned theme and subthemes. Moreover, the study drew the implications of the identified ideologies to the thinking of the Vietnamese youth. These speeches constituted the primary and twining sources of the study. From these literatures, readers will be able to glean in them the system of ideas and ideals of this world leader, especially those that forms the basis of political theory and policy.Other speeches of Ho Chi Minh which have undertones of his ideologies were not included in the study.

\subsection{Treatment of Materials}

The relevantrequirements in the treatment of materials were taken into consideration in the conduct of the research.Like all the other arts, literature has certain merits by which all selections can be measured for evaluation and analysis. According to Garcia, et al. (2000) [15], there are seven standards by which literary works can be measured for evaluation and analysis that would serve as guide in the selection of works that were included in the paper. Great literature, according to them, is 
distinguished by the following standards: permanence, universality, intellectual value, suggestiveness, spiritually value, artistry and style.

As regards the quality of permanence, it is worth mentioning that the selected works endure and their appeal is lasting. Great literature does not favorably dispose any beautiful thing to perish. These works may be read and re-read as each reading gives new discernments and pleasures and opens new realms of experiences and meanings. With reference to the quality of universality, it is significant to note that the identified literary pieces are timely and timeless. They are forever germane and appeals to everyone, anytime, anywhere since they deal with fundamental feelings, fundamental truths and universal conditions.

In relation to the quality of being intellectually valuable, it is of great essence to cite that the selected literary pieces stimulate the thought. They help the readers to enrich their ideological life by making them mindful of the basic truths about human nature and life.Regarding the quality of suggestiveness, it is essential to consider that the chosen literary pieces manifest appeal not only to the intellect but more so to emotions and imagination. It is not so much what they say as what they awaken in the readers that constitute their charm. They open a door through which an idealized or poetic creation enters a new world of music, beauty, love and many other values.

Relative to the quality of being spiritually valuable, it is noteworthy to mention that the selected works have underlying moral message that can elevate the readers' spirit by unveiling the moral values which transform them into better persons. This ability to inspire is part of the spiritual value of literature. With reference to artistry, it is significant to note that the chosen works appeal to the readers' sense of beauty. The selections, like all art forms are expressions of life in forms of beauty and truth. They are the reflection of some truth and beauty in the world but which remain unseen until revealed to the readers' attention by some sensitive human soul.

And finallty, in connection to the quality called style, it is essential that the selections have their distinctive quality, form or type. They share the eccentric way in which the writers see life, shapes their ideas and expresses them. Great works are remarkable as much by their memorable substance as by their distinctive style.

In subjecting the materials to internal and external criticism and analysis, the signification and authenticity of the statements in the aforecited sources were carefully chartered and analyzed. Relative to this, the researchers were free in their own view to upholdtheir understanding and evaluation of each literary piece according to their responsiveness in relation to the concept of ideology evoked in them, by delineating the appropriateness of the language to the theme, the relevance of the language to the situation, and the suitability of the language to the literary pieces under study.

\section{RESUltS AND DisCUSSIONS}

\subsection{The Ideologies Reflected in the Selected Speeches of Ho Chi Minh}

Ideology is commonly understood as having a core thought that basically refers to a human being's ideals, beliefs, or philosophical views, and how man formulates those lessons into being of influence to his future. It is the creed by which every human being strives to live by. It is the casting mold by which man's character is forged and stamped. While it is very important for an individual's character to possess a uniqueness that distinguishes himself from others, it is equally important that man's character is shaped, or at the very least, inspired by people who have made their mark on this world: great leaders and people of remarkable influence who, even long after they are gone, their ideology will continue to impact society by virtue of inspiration. Ideologies leave a solid mark, those that are bequeathed to and embraced wholeheartedly by any individual, family, community, nation or state that wills itself to come out of its limited comfort and security, and out into the world that offers boundless opportunities for change.

PresidentHo Chi Minh, who is commonly known as Uncle Ho in Vietnam was a Marxist-Leninist Revolutionary leader who served as Prime Minister from 1945-1955 and as President of the Democratic Republic of Vietnam from 1945 until his death in 1969. Ho Chi Minh's Selected Articles and Speeches is a collection of the President's writings and speeches during the period from 1920 to 1969, the main points of time in his life as a revolutionary cadre. Ho Chi Minh as a communist party leader and the President of Vietnam has written animmense number of articles and delivered different speeches, which should account for more than a thousand pages of a book. 
The selected writings reflect the main political activities in Ho Chi Minh's life that proved to be of great influence to the Vietnamese revolution. These literary works very well exhibited Ho Chi Minh's ideology expressed in his ideological strategy on continuous proletarian revolution specifically on national liberation manifested through independence and unity; on national independence and unity expressed through democracy, freedom, hapiness, and welfare; and on socialism as one of his ideologies' major creative points.

Ho Chi Min, with his ideology as a leader, proved that the inevitable rule of development and victory of Vietnam's revolution in the new era was an absolute imperative. He pointed out that to ensure the ultimate victory for Vietnam's revolution, the entire nation should learn from the Russian revolution. He came to the conclusion that prototypes on the Russian revolution could be a comprehensive one, which may eventually set the nation and the laborers free. He believed that only by adhering to Marxism-Leninism can one truly comprehend the correlation among democracy, national independence, and socialism, and have an accurate andfull-blown vantage point on national independence [16].

However, Ho Chi Minh did not have a conformist or dogmatic attitude on the inquiry regarding the particular course of action to be taken relative to Vietnam's revolution and, thereafter, on improving and securely setting it. He started by understanding the real situation of Vietnam, then endeavored to deal with the basicideas of Marxism and Leninism on proletarian revolution, primarily dialectical materialism, and strived to createa comprehensive and thorough analysis of the representative characters of the society so that they may precisely identifythe tactical and strategic issues as well as the steps to be taken toaccelerate Vietnam's revolution[16].

Ho Chi Minh lists national liberation at his topmost priority being one of the two basic strategic tasks of the national democratic revolution in Vietnam. In his perception, national unity and independence are always connected withdemocracy, freedom, happiness and welfare of the people, particularly the working class. Forhim, the people can only enjoy the benefits and values of independence and freedom if their daily life necessities are supplied and if their demands for basic living conditions are satisfied. Accordingly, Ho Chi Minh's ideology on national independence and unity has profound and all-encompassingelements, which embracesfreedom, democracy, welfare and happiness. His ideadeveloped theaim, the standard, and the slogans which inspired and mobilized the Vietnamese people to actualizeastoundingaccomplishments by overcoming all adversaries and by bringing full unity and independence to the country[16].

Specifically, Ho Chi Minh's Selected Articles and Speeches reflect his concepts on socialism in Vietnam, which is one of the major creative points of Ho Chi Minh's ideology. Ho Chi Minh emphasized socialism -- socialism that is not being limited to the theoretical and abstract. In his concept, a socialist society is a society where every person is equally treated, where its citizens can enjoy the benefits and social welfare. In a nutshell, a socialist society must be a good society of happy people.

In Ho Chi Minh's perspective, socialism is not only a vision or a destination, but a journey that needs to be undertaken by the Vietnamese nation. His statements on socialism may show diversity in line with specifiable details, words and phrases, but they all have the same well-established points. First, regarding the mastership of the people, he highlighted that all the authorities and forces come from the people. Second, he defined the "rich people and prosperous country" as the gradationaleradication of injustice and exploitation on the basis of development and production,and efforts to gradually "turn Vietnam from an agriculturally backward country into a country with modern industrial agriculture and advanced science and technology." Third, Ho Chi Minh hinges economic development with social policies anchored on efforts to steadilyimprovethe material, social, and spiritual living conditions of the people from all nationalities so that all their people will "have adequate food, clothes, housing, and have access to education" [16].

Next, he requires that in a socialist society, people of all nationalities throughout the country should enjoy equality and friendship among all the nationalities in the spirit of mutual efforts, mutual benefits, mutual reverence of independence, and sovereignty. Finally, Ho Chi Minh declares the aims of socialism -- the goals that a socialist society should attempt to achieve. What is more important is that he was likewiseconvinced of the immense creativity of the people and his belief that socialism 
must be brought into being by the people themselves. He underscores that Vietnam needs a political system under which power justly belongs to the people, by the people, and serves the best interest of the people, instead of a wealthy minority. These are the real values of socialism [16].

Ho Chi Minh's viewpoint on socialism is in congruence with thebasic perspective of MarxismLeninism on socialism; with the goalsas well as thefundamental and pressing requirements of the Vietnamese nation; and with the guidelines on the innovativedirections of Vietnam. Thus, these perspectivesmayhasten their course in the hearts of the Vietnamese people who purposely strive to sustain them [16].

\subsection{The Themes of Patriotism, Humanism, Inner Peace and Moral Principle Reflected in the Selected Speeches}

\subsubsection{The Theme of Patriotism in the Selected Speeches}

Patriotism, generally speaking, is an emotional attachment to a country or nation which individuals recognize as their homeland. This attachment, also referred to as national pride, can be regarded in terms of the different features relating to one's own nation, including cultural, ethnic, historical, or political aspects.

As regards the theme of patriotism in Ho Chi Minh's Selected Articlesand Speeches, it is worth noting that Ho Chi Minh is a lofty symbol of genuine patriotism. His name Nguyen Ai Quoc, which means Nguyen-the Patriot, and which was used as his penname during the 30 years of his search for the path towards national liberation, shows that he is someone who loves his country.

Hence, it can be said that Ho Chi Minh's ideology is a reflection of Vietnam's cultural traditionsparticularly patriotism, benevolence and national cohesion. It was his great love for his country and his countrymen, which is evident in The Path which Led Me to Leninismthat drove him to leave his beloved Fatherland to seek for the path to national salvation. It was his patriotism which helped him to overcome all the difficulties and challenges so as to devote his whole life to the revolutionary cause of Vietnam. Ho Chi Minh's life is a clear and vivid example of patriotism. He devoted his thoughts and actions for the sake ofhis country and people. All of his thoughts and actions were also for the sake of his country and his people. This is in consonance with Goldman's (1908) [17] impression which highlights patriotism as a love for one's country -- a supportive, respectful love that is immense and secure enough, to also question, challenge, and face the shadows of the past or present, without fear of breaking that deeper connection.

In his whole life, Ho Chi Minh attached his commitments to the revolutionary cause of his nation. $\mathrm{He}$ also attached his happiness to the happiness of his fellow countrymen. HisTestamentis a manifestation that before he died, the man who has devoted his whole life to the independence and freedom of his country and to the happiness of his people still expressed his regrets that he was not able to serve his country for a longer period of time. Ho Chi Minh's last words, which shows his dedication to his Fatherland, are a great example of his patriotism. Studying about his thoughts, the readers understand that patriotism serves as the motivational force that introduced him to Marxism-Leninism and paving the path towards the creative implementation of the theory in the context of Vietnam.

As drawn from Ho Chi Minh's speeches on patriotism, it can be gleaned that patriotism is a sacred emotion closely related to the spiritual consciousness of his Fatherland. It is regarded as a product of thousands of years of building and defending the country of the Vietnamese people. Furthermore, Ho Chi Minh's exemplary patriotism is a lighting torch that guides Vietnamese people towards good virtues and good actions for the sake of the country. Infusing his ideology with patriotism helps teach the responsibility to strive to live better.

\subsubsection{The Theme of Humanism in the Selected Speeches}

In mankind'sideological history, there are numerous theories andideologies which deal with human fate and reflect the aspirations and feelings of people who yearn to be freed from the predicament in their lives as well as from the limitations and constraints of nature and society. All these refer to humanitarianism and humanism, which have been explicitly expressed in diverse perspectives, approaches and levels[16].

In connection with the theme of humanism in Ho Chi Minh's Selected Articles and Speeches, it is noteworthy to mention that Ho Chi Minh's humanism is reflected first and foremost in his immense 
and profound feelings of love for humanity. With his own eyes, during his childhood and during his thirty years abroad, Ho Chi Minh did witness countless sufferings brought about by injustice and oppression. He did substantiatethe slums where the workers and the pariah people in Paris lived, the life of the black American people, and the radical discrimination and destitution of the working class in capitalist countries. These information and situationscreated a deep-deated markin his heart and mind.

By reflecting on these experiences, Ho Chi Minh merges the altruism inherent in Vietnam's cultural traditions with the ideas of humanism and benevolence of the East, as well as the ideas of fraternity, human emancipation from the royal and divine power as espoused by Western humanism, and in particular with Communist humanism. All these elements work together to produce in him lofty, profound and genuine humanism [16].

In the introductory article of Le Paria (The Outcast) [18], Ho Chi Minh distinctly defined that the objective of the struggle of the Association of Oppressed Nation was tofree the slaves who have lost their countries andto emancipate the people from their sufferings.

The eminent and distinct feature in Ho Chi Minh's humanism is his love and compassion for "the outcast." In his viewpoint, "the outcast" include the people of Vietnam and other colonies; those who have been corrupted and driven into ignorance; those who are exploited, oppressed, and condemned to destitution and poverty; those who have been condemned to forced labor and have served as mercenaries for their mother countries; and those who have lost their countries and have to live as slaves, without freedom and justice. "The outcast" also comprises the workingclass in capitalist countries who directly produce wealth but must live in poverty and deprivations. They are those poor workers who render services to produce goods yet remain starving [16].

As Ho Chi Minh lived among the common people, he understood their feelings, aspiration and strength. His love and compassion for these people were associatedwith his unshakeable faith in their strength, spirit of initiative and creativity as well ashis deep respect for them.

In Ho Chi Minh's era, guided by his ideology, the people are highly appreciated and their role in the revolution is highly valued. According to him, human beings are the roots of the country specifically, the villages. In order to foster the strength of the masses, it is essential that the Party as well as its members should set the objective to serve the people and practice fraternity. This is a commitment that Ho Chi Minh has always kept throughout his life and advised the Party cadres to follow to ensure that the people as the owner of the country are best served.

In a nutshell, Ho Chi Minh's thoughts of humanism during his era is associated with the genuine humanismof the Vietnamese people, which involves love and compassion for the people, particularly for those who are suffering. It can be drawn from the analysis of Ho Chi Minh's ideology on humanism that his humanitarian values are reflected in his life, career, morality, and lifestyle. The highest goal of Ho Chi Minh's humanism is for man to be completely liberated and become a true master of his country and the world. The goal of the Communist Party, the Government and the State is to make the Vietnamese citizens become real masters of the country and the world. This is a great challenge for the people of Vietnam, which requires efforts and talents in order to fulfill the said responsibility.This view justifies Childs' and Fowler's (2006) [19] concept which underscores the idea of an autonomous human being and the essential belief in its innate good nature.

\subsubsection{The Theme of Inner Peace in the Selected Speeches}

Inner peace, or peace of mind, can be regarded as one's bliss, happiness and contentment in life despite of how busy and stressful life is. Therefore, in order to have a better insight of inner peace, it is essential to understand the domains of peace as gleaned in the selected works.

Thinking positively and enthusiastically together are considered as methods to achieve inner peace. As a leader of his country, even though he is facing difficulties, Ho Chi Minh often expresses his optimism and hope in his speeches in order to inspire and encourage his audience.

With reference to the theme of inner peace in Ho Chi Minh's Selected Articles and Speeches,Ho Chi Minh was shown as a human being with extraordinary strong will and a revolutionary optimism amid the most difficult circumstances. 
When the speechFor a Lasting Peace, For a People's Democracy was delivered, Vietnam was in the middle of the resistance war against the French troops and facing a lot of hardship. Yet, in this circumstance, Ho Chi Minh could foresee the ultimate victory of the Vietnam revolution. He strongly believes not only in the splendid future of Vietnam but also in the bright future of world peace and socialism. This optimism is essentially required in the character of a leader of the country. His faith in the success of socialism suggests more thoughts and actions towards the nation's ideals.

The theme of inner peace in Ho Chi Minh's works can best be seen in his Testament in 1969, where he left a clear message of optimism for the Vietnamese people. His testament mapped a specific plan of action for the Vietnamese people which will serve them well for many years in the future. And with every specific line he gave to a specific sub-group that composed the nation as a whole, the theme of inner peace was clearly present. He closed his testament with the theme of inner peace easiest to understand - a conclusion to what his life was all about, a final message that summarizes his faith and optimism in his nation.

Ho Chi Minh's optimism underscores his belief in the importance of. When people believe in the brightness of the future, they have more motivation to fulfill their entire task. This idea is supported by Linden's (2014) [20] concept, which emphasizes peace contexts that can be seen as positive domains in which individuals may behave peacefully, hold peaceful attitudes, and experience peaceful states. All of these realms are germane to the construct of an optimistic tranquil psycheas people actively search to find the solutions to his problems.

\subsubsection{The Theme of Moral Principle in the Selected Speeches}

Ho Chi Minh with his role asthe leader understands the necessity of establishing moral principles in order to maintain order within the society. In its broad sense, moral principles refer to the principles of right and wrong that are accepted by an individual or a social group. In its narrow sense, moral principles are synonymous to ethics, which pertains to the moral rules that an individual or group live by. Ho Chi Minh used the term of ethics a lot in his speeches.

With reference to the theme of moral principle in Ho Chi Minh's Selected Articles and Speeches, it is essential to note that ethics is a basic component of Ho Chi Minh's moral pinciple, and originates from the demand for national, social and human liberation.

First of all, Ho Chi Minh regarded revolutionary ethics as the root and the basis of a revolution. He regarded ethics as the pivotal factor for the success of aradical cause. He underscored that the leader of the revolutionary movement must have ethics; otherwise, he cannot take the responsibility of leading the people. He did not raise the banner of revolutionary ethics in general, but he, initially, presented general standards of ethics that everyone and every social level should adhere. These includeallegiance to the Communist Party; devotion to the country and the people; inculcating the values of industry, integrity, righteousness, and frugality; overcome egoism and individualism; and fostering benevolence, courage, modesty, sincerity, solidarity, and unity and so on. This finding is supported by the Philosophy-religion.org Website's (2015) [21] concept, which highlights the view that under moral acts and ethical codes, human beings should be treated as subjects, not objects, as human life is of significant value. He then pointed out specific standards that particular groups should adhere to in accomplishing their specific duties and responsibilities.

Relative to the citizens, he averred that their country is a democratic country, that is a country where the people are the masters and that they have the right and interest to act as the masters of their country. Consequently, they have the responsibility to fulfill their duties and abide by the ethics of citizens, which include abiding by the laws of the State and by labour discipline, preserving general order, payingthe right taxespromplty, defending public property and the Fatherland, and enthusiastically taking part in general work and activities[16].

Moreover, Ho Chi Minh is great in thinking and setting up strategies. He understood that his people are ordinary working people who need specific guidelines and detailed teachings. Therefore, he told the Communist Party members, the armed Forces, the children and teenagers, and the women what they need to follow and to abide.

Ho Chi Minh also gave diverse specific instructions to cadres working in various fields. He realized that the success of the revolutionary cause depends on the people and the society is built up by each 
social cell. Consequently, he placed equal demands of ethics for each social stratum, each specific group, each class member and each citizen. He never gave general instruction on ethics to people. With different groups of people, his teachings vary so that the required ethics are specific, appropriate and achievable.

To sum up, how revolutionary ethics should be built is a matter of great concern to Ho Chi Minh and is a significantelementin the study of ethics. The understanding of Ho Chi Minh's ideology on moral principle revealed that people's values are given priority. He highly appreciatedthe thought that there is nothing more valuable than the people, that nothing is as strong as the people's solidarity, and that the most precious thing in life is democracy. As power owners, the people must be the owners of democracy and society. They should also be capable of being in charge of their State. He also emphasized that anextensive democracy is the key to resolving difficulties. From this vantage point, he distinctly discern democracy's role as the motivating power behind progress and socialism.

Ho Chi Minh's theory of socialist construction was scientific and revolutionary as well ascultured, moral, and humanistic. He strongly believed thatsocialism in concordance with science will inevitably draw mankind to eternal happiness. People should build and foster socialism to improve people's material and spiritual lives to make a more civilized and progressive society. All are aimed at the people's happiness.According to Ho Chi Minh, the key to socialist construction is to rely on the people, mobilize theircapacity and make them happy. The people's free development, democracy and social equality as well as the right to mastery and happinesswere values that guaranteed the sustainable development of thegovernment. Socialism was a highly developed cultural society in which the people were the masters and the nation was a discerning nation [22].

\subsection{The Implications of Ho Chi Minh's Ideologies to the Thinking of the Vietnamese Youth}

Ho Chi Minh's ideology is a comprehensive system of viewpoints on the fundamental issues of the Vietnamese revolution and the results of the application and creative development of MarxistLeninism in day to day life in Vietnam. It is the inheritance and development of the nation's traditional values and the assimilation of the very essence of humanity. It is the strategic and tactical theory on the revolution for national liberation and the advancement to socialism. It is the science of the law of development of a semi-feudal and colonial society with a less developed economy. It is the ideological system in the new era of the working class and people of different nationalities.

In his lifetime, Ho Chi Minh always provide special attention to and highly valued the role of younger generations. His speeches revealed the great importance of the youth. Thus the latter should be fully aware of Ho Chi Minh's thoughts so that they can successfully implement his ideology in the building and defense of the country.

Learning Ho Chi Minh's ideologies and following his moral example, the Vietnamese youth should bear the responsibility to continue Vietnam's revolution: a revolution for national liberation; building the people's democratic regime; and proceeding towards socialism without going through the period of capitalist development. These are all geared towards the attainment of a democratic, independent, peaceful, prosperous and unified Vietnam and themaking of a worthy contribution to world revolution (Paloma-halongcruise.com Website, 2019) [16].

The Vietnamese youth today are very much priveleged to be born and to grow up in a completely independent country. Unlike their grandparents and parents, who have to struggled against different adversaries, they can enjoy full freedom of a liberated Vietnam. The wish of Ho Chi Minhthat the country will beunited and free from any antagonist has been fulfilled. The Vietnamese people have gained the privilege of sovereignty and are embarking on a new era -- theage of mainstreaming socialism throughout the country.

However, at present, Vietnam is still facing challenges. In the current context, it is required that the youth shouldunderstand their responsibilities in nation building in terms of learning, working, defending the nation's sovereignty and cultivating revolutionary ethics.The youth, as the future master of the country, is supposed to study hard to raise their professional qualifications and educational levelsand to participate in building an academic cultured environment. They are also expected to take the pioneering move in educational and training programs in order to build a learning society.

Though Ho Chi Minh inspires all people to pursue learning, he never encourages them to learn theory solely. Many times, he recommended that the youth should attach the content of education to 
Vietnamese reality, stick learning with practice, link theory to reality and especially combine learning with productive labor.

Moreover, it is necessary that younger generations have a spirit of fondness of learning and aspire after progress. Following the great example of Ho Chi Minh, the youth should apply his thoughts of self-teaching and self-training so that learning becomes a lifetime process and the amount of knowledge and experience to be accumulated are increased exponentially.

National liberation and national independence are the two core contents of Ho Chi Minh's ideology. Today, when the whole country is enjoying full freedom and independence, the responsibility to defend the country and the people has been put on the shoulders of the youth. Younger generations should be responsible for defending their country. Their grandparents and parents have sacrificed their lives to gain the freedom for the country and to seize back the national independence. Hence, it is the sacred duty and noble right of the youth to protect their parents' revolutionary results - to defend their Fatherland. Some specific actions that young generations can take so as to practically protect the country include taking part in defense education programs, fulfilling military service duties, joining the uniformed services according to the prevailing laws, participating in building the universal defense system, upholding national secrets, taking the lead in combating all acts that infringe upon national security and social order and safety.

Furthermore, revolutionary ethics are not readily available but are the upshot of a constant struggle. Thus, the youth must always enlighten themselves with revolutionary ethics. They should show selflessness and public-spiritedness in dealing with other people and in their work, strive to lead a clean life, have an ardent desire for progress, and always be united. They should actively fight against individualism, do away with negative practices, and carry out regular constructive criticism to help each other make progress. These practices are fundamental to the cultivation of revolutionary ethics among the youth of Vietnam.

Ho Chi Minh himself set an excellent example in his tireless struggle for national liberation and independence and human liberation. Therefore, through his writings, young generations can absorb his ideology and implement good practices as in the words of the song: "Thinking about Uncle Ho, our hearts become kinder."

\section{CONCLUSIONS AND RECOMMENDATIONS}

Ho Chi Minh's selected speeches vividly exhibited the aspects of his political ideologies as expressed in his ideological strategy on continuous proletarian revolution specifically on national liberation manifested through independence and unity; on national independence and unity expressed through freedom, democracy, welfare and happiness; and on socialism as one of his ideologies' major creative points.Moreover, themanifestations of the themes of patriotism, humanism, inner peace and moral philosophy are also evident in the literary works. With regard to the implications of his ideologies to the thinking of the Vietnamese youth, Ho Chi Minh's ideologies serve as the lighting torch leading the youth towards positive thinking, good virtues and practical actions contributory to the building and defense of their country.From the foregoing findings and conclusions, the researchers offer the following recommendations: That college instructors of literature may use this analysis as one of their methodologies in teaching literature specifically the appropriate materials, media, and literary theories and approaches in literary analysis in their literature classes; That the students of literature realize the significance of the literature as a work of art distinguished from other texts through content, and intensify their appreciation of literary works as well as inspire them to engage in literary analysis as a form of academic exercise; That the researchers may learn the analytic skills necessary in interpreting literary pieces through the present study with a broadened understanding of the ideologies of other world leaders; and That future researchers may conduct other literary works in the veins of the recent research, for academic enhancement to have cross references leading to a better dissection of views to further substantiate the present study.

\section{ACKNOWLEDGMENTS}

Dr. Nguyễn Thị Hồng Minh would like to express her sincere thanks and appreciation to those who have made contribution to the implementation of this study. First and foremost, she wishes to thank Prof. Dr. Maria Luisa A. Valdez, her co-researcher and adviser, for her expertly professional and caring communication during the writing process. Likewise, her deep gratitude goes to the Thai 
Nguyen University leaders, especially Prof. Dr. Pham Hong Quang, the Director, Assoc. Prof. Dr. Nguyen ThiTinh, Vice Rector and Assoc. Prof. Dr Do Hong Thai, the Chairman for University Council, for the motivation during the completion of this research.

Prof. Dr. Maria Luisa A. Valdez wishes to express her grateful appreciation to Dr. NguyenThiHong Minh, for the invaluable effort she has put in on this paper as her co-researcher. To Prof. Dr. Tirso A. Ronquillo, the Batangas State University President and the other University officials most especially to Prof. Dr. Erma B. Quinay, the Vice President for Academic Affairs, Engr. Albertson D. Amante, the Vice President for Research, Development and Extension Services and Prof. Enrico M. Dalangin, the BatStateU ARASOF Nasugbu Executive Director, for the motivation that helps hasten the completion of this study. To Mr. Thaakor Pathak, for his wisdom that drew up essential and relevant dimensions in this research. To the pool of writers whose works were included in this study for posterity, for their emboldened wisdom in every page of this research. To the Almighty God and to all of you, the researcher owes her deep gratitude.

\section{REFERENCES}

[1] Lye, John (2008) The Language Theses. Retrieved from: https://www.brocku.ca/english/jlye/uses.php; date retrieved: $10 / 15 / 2015$.

[2] Honderich, Ted (1995). The Oxford Companion to Philosophy. Oxford University Press. ISBN 978-0-19866132-0.

[3] Cliffsnotes.com Website (2016). Political Ideology. Retrieved from: https://www.cliffsnotes.com/studyguides/american-government/public-opinion/political-ideology; date retrieved: 11/21/2018.

[4] Abramovitz, Mimi (2013) Political Ideology and Social Welfare. Encyclopedia of Social Welfare. Retrieved

from: http://socialwork.oxfordre.com/view/10.1093/acrefore/9780199975839.001.0001/acrefore-9780199 975839-e-292; date retrieved: 11/21/2018.

[5] British Political Speech Website (2015) Why Rhetoric? Retrieved from: http://www.britishpoliticalspeech. org/why-rhetoric.htm; date retrieved: 10/15/2015.

[6] Ho Chi Minh Biography.com Website (2015)Ho Chi Minh's Biography; Retrieved from: http://www. biography.com/people/ho-chi-minh-9340663; date retrieved: 10/15/2015.

[7] Time 100 Magazine -- U.S. Edition -- April 13, 1998 Vol. 151 No. 14.

[8] Stanley Karnow, 13 April 1998, Ho Chi Minh, TIME.

[9] Interview with William Duiker on HồChí Minh: A Life, 12 November 2000.

[10] DeCaro, Peter A. (2003) Rhetoric of Revolt: Ho Chi Minh's Discourse for Revolution; Praeger (February 28, 2003); Retrieved from: http://www.amazon.com/Rhetoric-Revolt-Minhs-Discourse-Revolution/dp/ 0275974111; date retrieved: 10/15/2015.

[11] Suter, W. Newton (2012). Introduction to Educational Research. University of Arkansas at Little Rock Sage Publications, Inc.

[12] Ary, Donald, Lucy Cheser Jacobs, Asghar Razavieh, Christine K. Sorensen. (2006) Introduction to Research in Education. Wadworth: Belmont, California, USA.

[13] Patton, M. Q. (2002) Qualitative Research and Evaluation Methods. Thousand Oaks, California, USA: Sage.

[14] Ho Ch Minh (1969). Ho Chi Minh's Selected Articles and Speeches (1920-1967).

[15] Garcia, Carolina U., Piedad G. Rosales and Corinta G. Barranco (2000) A Study of Literary Types and Forms. UST Publishing House, Manila Philippines.

[16] Paloma-halongcruise.com Website (2019). Revolution Path of Vietnam. Retrieved from: https:// www.paloma-halongcruise.com/travel-info/Revolution_Path_of_Vietnam/; date retrieved: 02/22/ 2019.

[17] Goldman, Emma (1908) What is Patriotism? Retrieved from: http://www.edchange.org/multicultural/ speeches/emma_goldman_patriotism.html/; date retrieved: 10/15/2015.

[18] Ho Chi Minh (1921) Le Paria (The Outcast). French Journal, France.

[19] Childs, P., Fowler, R. (2006). The Routledge Literary Terms. Routledge, 2 Park Square, Milton Park, Abingdon, Oxon OX14 4RN.

[20] Linden, Nelson L. (2014). Peacefulness as a Personality Trait. Peace Psychology Book Series.

[21] Philosophy-religion.org Website (2015) Ethics and Morality. Retrieved from: http://www.philosophy religion.org/handouts/pdfs/ch7-ethics.pdf; date retrieved: 10/13/2015. 
[22] English.tapchicongsan.org.vn Website (2019). President Ho Chi Minh's Great Contribution to National Independence and Socialism. Retrieved from: http://english.tapchicongsan.org.vn/Home/Theory-andReality/2010/247/President-Ho-Chi-Minhs-great-contribution-to-national-independence-and-socialism. aspx; date retrieved: 02/22/2019.

\section{AUTHOR's BIOGRAPHY}

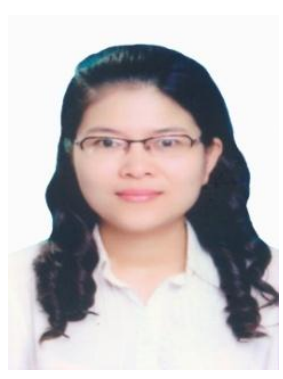

Dr. Nguyen Thi Hong Minh is the Dean of Faculty of Foreign Languages Education, Thai Nguyen University of Education, Vietnam. She has been teaching English to majors and non-majors at various levels for nearly 15 years as well as Vietnamese to international students from the USA, Taiwan, China, Mozambique, Mongolia, and Laos. Her research interests include teacher training curriculum, intercultural education and English instructions and methodology. She has published two (2) books; seven (7) papers in domestic journals and two (2) articles in international conferences. Her publication is devoted to the teaching and the research in English Language and Literature Education as well as the teacher education. She has been awarded the recognition from Vietnam's Minister of Education and Training and a number of other awards for her efforts and contribution to the university and the faculty. She has been selected as one of the candidates for a 8-week training project in New Zealand in teaching English to young learners funded by Vietnam's Ministry of Education and Training and another 6-week training course in Australia in gender equality and gender in management sponsored by Embassy of Australia in Vietnam.

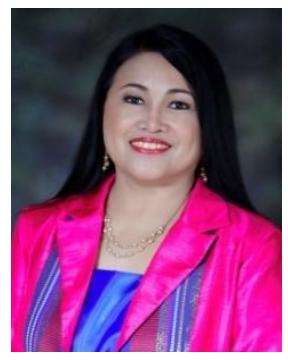

Dr. Maria Luisa A. Valdez is a Professor and the Associate Dean of the College of Arts and Sciences in the Batangas State University ARASOF Nasugbu Campus, Nasugbu, Batangas, Philippines. She has been in the teaching profession for more than 30 years. She is also a senior accreditor of the Accrediting Agency of Chartered Colleges and Universities in the Philippines conducting program assessment among various state universities and colleges. She has published fourteen (14) researches in reputable international refereed journals and presented papers on various local, national and international research fora. Likewise, she is an editorial board member and a peer reviewer of eleven (11) international refereed journals. Her papers won the Best Research Paper Awards in local and international research conferences. Her research interests center on education, humanities and social sciences specifically on contemporary social issues like peace education, gender equality, and environmental issues manifested in the selected contemporary literary works in English. She is a visiting professor and the dissertation adviser of seven (7) Doctor of Philosophy students of the Thai Nguyen University International Training and Development Center, Socialist Republic of Vietnam.

Citation: Nguyen Thi Hong Minh, Maria Luisa A. Valdez. Ideologies Reflected in the Selected Speeches of Ho Chi Minh" International Journal on Studies in English Language and Literature (IJSELL), vol 7, no.45, 2019, pp. 17-28. doi:http://dx.doi.org/10.20431/2347-3134.0704002.

Copyright: () 2019 Authors. This is an open-access article distributed under the terms of the Creative Commons Attribution License, which permits unrestricted use, distribution, and reproduction in any medium, provided the original author and source are credited. 